REVIEW ARTICLE

\title{
Spermidine metabolism in parasitic protozoa - a comparison to the situation in prokaryotes, viruses, plants and fungi
}

\author{
Annette E. Kaiser, Andrea M. Gottwald, Carolin S. Wiersch, Walter A. Maier and Hanns M. Seitz \\ Institut für Medizinische Parasitologie, Rheinische-Friedrich-Wilhelms-Universität Bonn, Sigmund-Freud-Strasse 25, 53105 \\ Bonn, Germany
}

Key words: spermidine, homospermidine, deoxyhypusine, eIF5A, drug therapy, Plasmodium, Trypanosoma, Leishmania

\begin{abstract}
Targeting polyamines of parasitic protozoa in chemotherapy has attracted attention because polyamines might reveal novel drug targets for antiparasite therapies (Müller et al. 2001). The biological function of the triamine spermidine in parasitic protozoa has not been studied in great detail although the results obtained mainly imply three different functions, i.e., cell proliferation, cell differentiation, and biosynthesis of macromolecules. Sequence information from the malaria genome project databases and inhibitor studies provide evidence that the current status of spermidine research has to be extended since enzymes of spermidine metabolism are present in the parasite (Kaiser et al. 2001). Isolation and characterisation of these enzymes, i.e., deoxyhypusine synthase (EC 1.1.1.249) (DHS) and homospermidine synthase (EC 2.5.1.44) (HSS) might lead to valuable new targets in drug therapy. Currently research on spermidine metabolism is based on the deposition of the deoxyhypusine synthase nucleic acid sequence in GenBank while the activity of homospermidine synthase was deduced from inhibitor studies. Spermidine biosynthesis is catalyzed by spermidine synthase (EC 2.5.1.16) which transfers an aminopropyl moiety from decarboxylated S-adenosylmethionine to putrescine. Spermidine is also an important precursor in the biosynthesis of the unusual amino acid hypusine (Wolff et al. 1995) and the uncommon triamine homospermidine in eukaryotes, in particular in pyrrolizidine alkaloid-producing plants (Ober and Hartmann 2000). Hypusine is formed by a two-step enzymatic mechanism starting with the transfer of an aminobutyl moiety from spermidine to the $\varepsilon$-amino group of one of the lysine residues in the precursor protein of eukaryotic initiation factor eIF5A by DHS (Lee and Park 2000). The second step of hypusinylation is completed by deoxyhypusine hydroxylase (EC 1.14.9929) (Abbruzzese et al. 1985). Homospermidine formation in eukaryotes parallels deoxyhypusine formation in the way that in an $\mathrm{NAD}^{+}$-dependent reaction an aminobutyl moiety is transferred from spermidine. In the case of homospermidine synthase, however the acceptor is putrescine. Thus the triamine homospermidine consists of two symmetric aminobutyl moieties while there is one aminobutyl and one aminopropyl moiety present in spermidine. Here, we review the metabolism of the triamine spermidine with particular focus on the biosynthesis of hypusine and homospermidine in parasitic protozoa, i.e., Plasmodium, Trypanosoma and Leishmania, compared to that in prokaryotes i.e., Escherichia coli, a phytopathogenic virus and pyrrolizidine alkaloid-producing plants (Asteraceae) and fungi.
\end{abstract}

\section{INTRODUCTION TO POLYAMINES}

The three polyamines such as putrescine, spermidine and spermine are naturally positively charged compounds found in virtually all living cells. These compounds bind to DNA and have been implicated in a number of crucial processes such as cell division, differentiation and membrane function. The inhibition of polyamine biosynthesis stops cell growth. One of the important polyamines involved in these processes is the triamine spermidine (Fig. 1).

The biosynthetic pathway of polyamines starts from arginine or ornithine catalyzed by arginine- (EC 4.1. 1.19) (ADC) or ornithine decarboxylase (EC 4.1.1.17) (ODC) to form the important intermediate putrescine. Spermidine is formed in the subsequent reaction by the transfer of an aminopropyl moiety from decarboxylated S-adenosylmethionine to putrescine by spermidine synthase (EC 2.5.15) (SPDS). In the final step of the polyamine pathway spermine synthase (EC 2.5.1.22) (SPS) catalyzes the propylamine transfer to the acceptor spermidine to form spermine.

The metabolism of putrescine, spermidine and spermine either leads to various types of oxidated products by oxidative deamination through polyamine oxidases or to conjugated amines preferentially in the acylated form through acetyltransferases.

The regulation of polyamines, however, in mammalian cells is quite complex. The biosynthesis of polyamines is stimulated by different external stimuli and regulated by feedback mechanisms (Müller et al. 2001). These sophisticated regulatory mechanisms enable cells to adapt to considerable changes of extra- and intracellular polyamine concentrations.

This is probably one of the reasons why it is so difficult to develop selective enzyme inhibitors as potent drugs. Nevertheless there remains optimism for parasitologists that these compounds in combination 
A<smiles>NCCCCCCN</smiles>

2<smiles>NCCCCNCCCN</smiles>

or spermidine<smiles>N[CH+]CCCN</smiles>

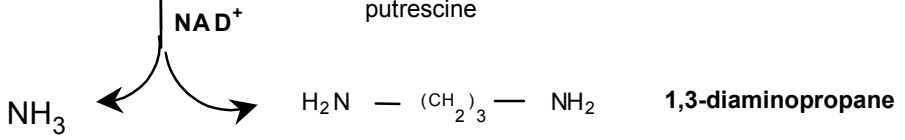<smiles>NCCCCNCCCCN</smiles>

homospermidine

B elF5A precursor - $\left(\mathrm{CH}_{2}\right)_{4}-\mathrm{NH}_{2}$

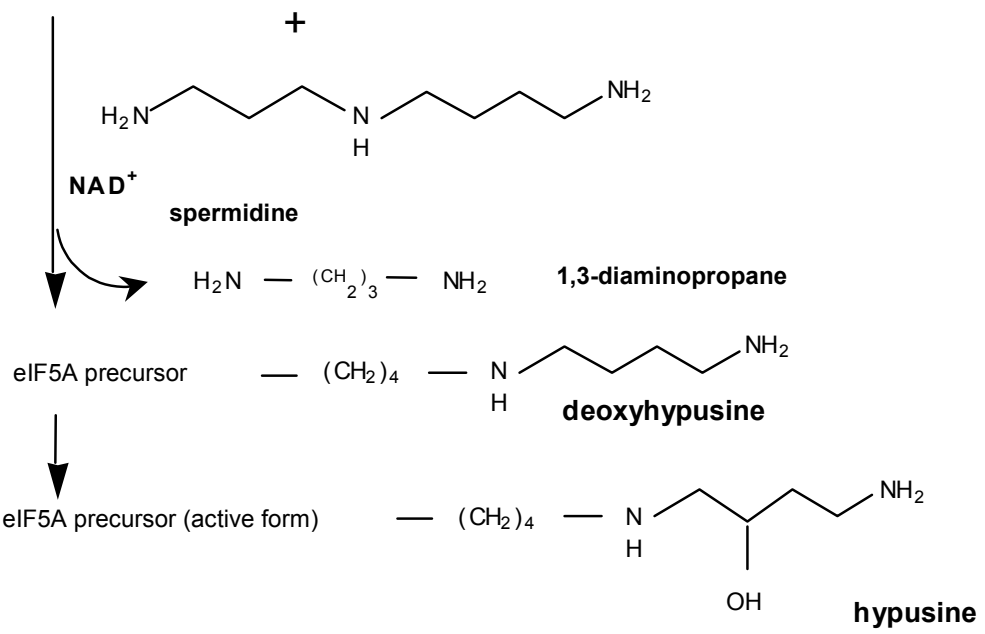

Fig. 1. A. A comparison between the formation of homospermidine and deoxyhypusine under catalysis of homospermidine synthase and deoxyhypusine synthase. Pathway leading to homospermidine in (1) prokaryotes, viruses and (2) eukaryotes. Homospermidine in prokaryotes and viruses is strictly formed from two moles of putrescine in an $\mathrm{NAD}^{+}$-dependent reaction. In eukaryotes the biosynthesis of homospermidine starts from putrescine and spermidine. B. Hypusine biosynthesis comprises two steps: In the first step deoxyhypusine synthase catalyzes the transfer of an aminobutyl moiety from spermidine to the $\varepsilon$-amino group of lysine in the eIF5A precursor protein to form deoxyhypusine. Hypusine formation is completed by deoxyhypusine hydroxylase in the second step.

with their structural analogues might be of benefit, affecting uptake, synthesis and regulation of polyamines simultaneously.

Studies on the biosynthesis of the uncommon triamine homospermidine (Fig. 1, A) in parasites have been initiated. To date, homospermidine synthase (EC 2.5.1.44) (HSS) which catalyzes the reaction to homospermidine has been characterised in bacteria (Tholl et al. 1996), a virus (Kaiser et al. 1999), and from plants (Kaiser 1999, Ober and Hartmann 1999b). While the prokaryotic enzyme strictly uses two moles putrescine in an $\mathrm{NAD}^{+}$-dependent reaction, the eukaryotic enzyme transfers the aminobutyl moiety from spermidine to putrescine (Fig. 1, B).

A novel amino acid, hypusine, produced in the metabolism of spermidine, is involved in the activation of eukaryotic initiation factor eIF5A. Hypusine biosynthesis comprises two steps: i) the transfer of the aminobutyl moiety from spermidine to the $\varepsilon$-amino group of a specific lysine residue in eIF5A by deoxyhypusine synthase (EC 1.1.1.249) (DHS). In this step deoxyhypusine is formed. ii) Hydroxylation by deoxyhypusine hydroxylase (EC 1.14.9929) completes hypusine biosynthesis (Fig. 1, B). Deoxyhypusine hydroxylase 
was purified from rat testis (Abbruzzese et al. 1986) and shown to be strongly inhibited by $\mathrm{Fe}^{2+}$. The specific enzymatic activity was increased by sulfhydryl compounds like dithiothreitol. Remarkable were the findings that deoxyhypusine hydroxylase showed different developmental patterns in rat brain with highest specific activities in young rat brain (Abbruzzese 1988). Catecholpeptides (Abbruzzese et al. 1991), $\alpha$-hydroxypyridones and the natural compound mimosine (Andrus et al. 1998) are potent inhibitors of deoxyhypusine hydroxylase. The only eukaryotic nucleic acid sequence published in GenBank is that from mouse.

Both enzymes HSS and DHS are similar in their mechanistic properties i.e., the formation of an enzymeimine intermediate, the $\mathrm{NAD}^{+}$-dependence and the transfer of the aminobutyl moiety from spermidine.

\section{SPERMIDINE BIOSYNTHESIS AND METABOLISM IN PLASMODIUM FALCIPARUM}

Spermidine biosynthesis in Plasmodium falciparum was mainly studied by inhibitor experiments elucidating its function in the cell cycle of the parasite. Assaraf et al. (1984) showed that polyamine levels increased in parasite-infected erythrocytes. The authors determined a 95-fold increase in putrescine and a 51-fold increase in spermidine in trophozoite and schizont enriched fractions. However, it became evident that human erythrocytes contain putrescine, spermidine and spermine although they lack nuclei and are devoid of the ornithine- and S-adenosylmethionine decarboxylase (EC 4.1.1.50) (AdoMetDC) (Fig. 2) activity. Presumably in non-infected erythrocytes these polyamines are taken up by the surrounding cells (Mishra et al. 1997). Inhibitor experiments have shown that both enzymes are ratelimiting enzymes in the biosynthesis of spermidine (Assaraf et al. 1984) (Fig. 1).

Blocking spermidine and spermine biosynthesis in $P$. falciparum-infected erythrocytes with MDL 73811, i.e. 5'(Z)-[4-amino-2-butenyl] metylamino-5'deoxyadenosine, an irreversible inhibitor of AdoMetDC, resulted in prevention of growth of the parasite in vitro (Wright et al. 1991). This inhibition could be partially reversed by coincubation of the parasites with spermidine and spermine, but not with putrescine. The inhibitor MDL73811 prevented progression of $P$. falciparuminfected erythrocytes into schizonts suggesting that the function of spermidine is of importance at specific stages of parasite development.

The biological function of spermidine in the biosynthesis of macromolecules has also been shown in $P$. falciparum. The maturation of young stages of $P$. falciparum (ring forms and trophozoites) to mature forms (schizonts) is accompanied by a massive synthesis of proteins and replication of malarial DNA. Bachrach and Abu-Elheiga (1990) demonstrated that spermidine increased the activity of a DNA polymerase from the malaria parasite $P$. falciparum by a factor of 6 .
Malaria parasites did not synthesize DNA after treatment with alpha-difluoromethylornithine (DFMO), an inhibitor of ODC suggesting the essential role of polyamines for the translation of the DNA polymerase. It was also demonstrated by Assaraf et al. (1987) that DFMO caused a partial inhibition of RNA synthesis and that synthesis of some proteins was completely blocked by DFMO. The authors concluded from their findings that putrescine and/or spermidine are required for the synthesis of certain proteins in parasitised erythrocytes.

Spermidine has a profound effect on the activity of topisomerases I and II. Topoisomerases I and II were purified from Plasmodium berghei (Riou et al. 1986) and found to be stimulated by spermidine tenfold.

During infection with $P$. berghei, mammalian polyamine biosynthesis is markedly and tissue-specifically activated. Most prominent is the induction of the specific activity of ODC in spleen of mice infected with P. berghei (Hibasami et al. 1994). Polyamine concentrations with maximum increase in spleen were also observed in infections with chloroquine-resistant and chloroquine-susceptible $P$. berghei in Mastomys natalensis (Mishra et al. 1997). An increase in spermidine was more significant when compared to the increase in putrescine and spermine.

Cloning of polyamine biosynthetic genes is currently in progress since sequence information from the malaria genome databases is available. The rate-limiting enzyme of the polyamine pathway, i.e., ODC has been recently cloned, sequenced and overexpressed in Escherichia coli by Müller et al. (2000) and was found to be a bifunctional enzyme. The recombinant, overexpressed protein exhibited AdoMetDC and ODC activity. The cDNA contains an open reading frame of 1419 amino acids with three domains: residues 1-529 show similarity to AdoMetDCs of different organisms, residues 530 to 804 function as a connecting peptide and the C-terminal $805-1419$ is homologous to known ODC sequences. The fact that ODC and AdoMetDC are combined in one protein that has not been found in any other organism so far might be exploited as a new approach in therapy. Expression of the mere recombinant ODC protein without the hinge region from $P$. falciparum and expression of the hinge region of the bifunctional ODC/AdoMetDC in conjunction with mere ODC showed that the hinge region is important for the catalytic activity of $P$. falciparum ODC (Krause et al. 2000). It was shown that odc/ adometdc transcription appears predominantly at the trophozoite stage, demonstrating that at this stage of parasite development the requirement of polyamines is high due to rapid growth and DNA synthesis. Recently the coding region of spermidine synthase from $P$. falciparum has been published in GenBank (Luersen et al. 2000, Bernhard Nocht Institute, Hamburg, unpublished document). SPDS from $P$. falciparum shares $42 \%$ 
A

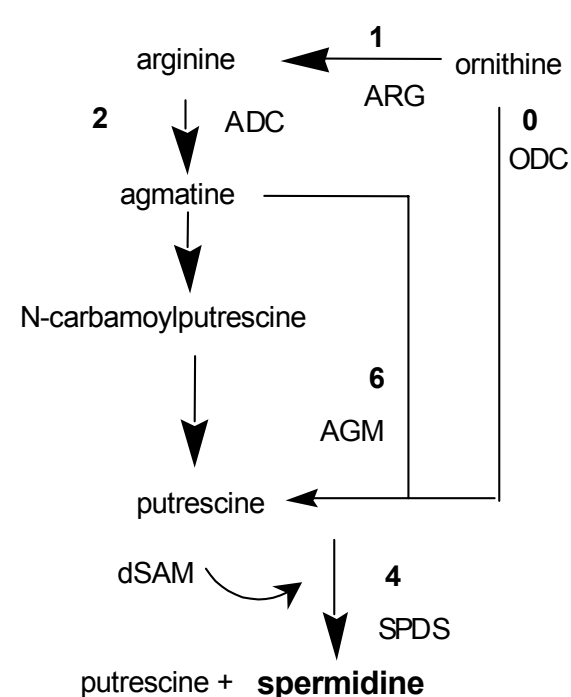

B

1

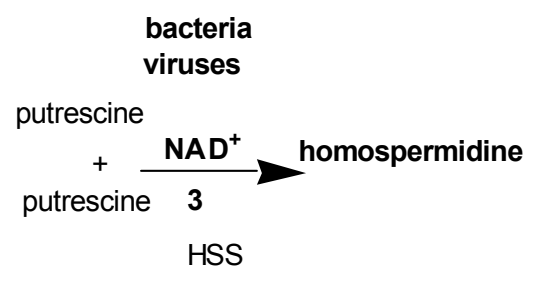

putrescine

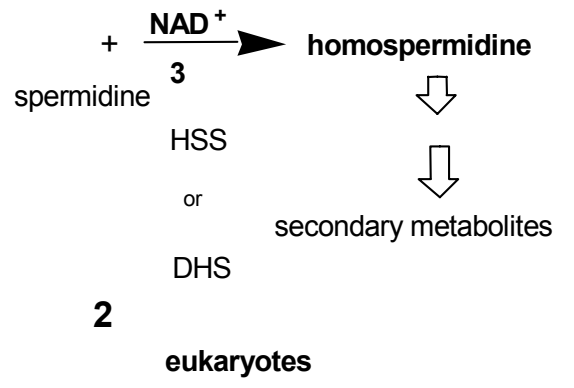

Fig. 2. A. The polyamine pathway in bacteria, plants and mammals. Two pathways exist for the biosynthesis of putrescine in bacteria, plants and mammals, i.e., the pathway via arginine and ornithine. Recently it was shown in mammals that putrescine can be formed from agmatine by agmatinase. 0 - ornithine decarboxylase (ODC), 1 - arginase (ARG), 2 - arginine decarboxylase (ADC), 3 - homospermidine synthase (HSS), 4 - spermidine synthase (SPDS), 5 - deoxyhypusine synthase (DHS), 6 agmatinase (AGM). The pathway from putrescine to homospermidine catalyzed by homospermidine synthase (HSS) is demonstrated in part B (3) of the figure. B. Two different pathways to homospermidine exist in bacteria, viruses (1) and eukaryotes (2) starting strictly from two moles of putrescine in bacteria and viruses (1) and putrescine and spermidine in eukaryotes (2). Homospermidine can be formed by DHS or HSS in eukaryotes.

nucleic acid identity to the human and $47 \%$ identity to the gene from Dictyostelium discoideum. The amino acid sequence of SPDS is highly conserved between different eukaryotic species and mainly conforms to the substrate-binding region of decarboxylated S-adenosylmethionine (Hamasaki-Katagiri et al. 1997). In this context it is remarkable that SPDS from E. coli shares significant homology to plant SPDS from Nicotiana sylvestris, Hyoscyamus niger and Arabidopsis thaliana (Hashimoto et al. 1998).

To date, polyamine biosynthesis has been elucidated from ornithine to spermidine while genes involved in spermidine metabolism have not been under investigation in P. falciparum. However, one of the important biological functions of spermidine is its role as a precursor in the biosynthesis of hypusine and homospermidine present in eukaryotes. Research on hypusine (Fig. 1) has just begun in P. falciparum.
Cell free synthesis of deoxyhypusine was first studied in Chinese hamster ovary cells (Park and Wolff 1988) after treatment with the inhibitor DFMO to enrich deoxyhypusine synthase. Later, deoxyhypusine synthase was purified and characterised from Hela cells (Klier et al. 1995) and rat testis (Wolff et al. 1995). Both enzymes are tetramers with a molecular mass of 41 to $43 \mathrm{kDa}$ comprising two associated dimers with four active sites. It is an interesting observation that three different transcripts for human deoxyhypusine synthase exist, which lends further support for a specialised gene expression programme of certain polyamine metabolic proteins. Similar results have been obtained for two different human eIF5A genes which are tissuespecifically expressed (Jenkins et al. 2001). Meanwhile, 247 deoxyhypusine synthase-coding genes ( $d h s$ ) from a variety of organisms have been published in GenBank. Among them are $d h s$ coding genes from parasites, i.e., 
Trichinella spiralis (Mc Carter 2001, Genome Sequencing Center, Washington, unpublished document), Cryptosporidium parvum (Strong and Nelson 2000), Trypanosoma brucei brucei (Hatt 2000, Sanger Center, UK, unpublished document), Trypanosoma cruzi (Aslund L. 1998, Biomedical Centre, Uppsala, unpublished document) and Leishmania major (Akopyants et al. 2001).

Recently the nucleotide sequence of a putative deoxyhypusine synthase from $P$. falciparum was published in GenBank by Molitor et al. (2000, Institute for Pharmaceutical Biology, Bonn, unpublished document) referring to the nucleotide sequence already deposited in the TIGR P. falciparum genome database on chromosome 14. In this context it is interesting to note that the putative deoxyhypusine synthase from $P$. falciparum shows $73 \%$ homology between amino acid positions 292 and 346 and complete identity between amino acid position 182 and 189 to plant homospermidine synthase from Senecio vulgaris (Asteraceae) (Kaiser 1999).

It was shown that the plant homospermidine synthase gene (hss), which is involved in plant secondary metabolism, recruits from the dhs gene involved in primary metabolism. HSS is similar to DHS in that i) both enzymes use spermidine as a substrate for the transfer of the aminobutyl moiety, ii) $\mathrm{NAD}^{+}$serves as a cofactor in both reactions, and iii) in both reactions an enzyme imine intermediate is formed. The genes encoding DHS of a variety of organisms are highly conserved concerning their substrate-binding site for spermidine since DHS is ubiquitous in eukaryotes. Most prominent is the striking homology in the region for substrate binding of spermidine and the cofactor $\mathrm{NAD}^{+}$ while the $\mathrm{N}$-terminus differs between different species (Lee and Park 2000). The homology in the substratebinding regions can only be deduced from the DHS amino acid sequence since these binding sites have not been identified for plant HSS as performed by Lee and Park (2000) for deoxyhypusine synthase using sitedirected mutagenesis.

The essential function of DHS in eukaryotic cell proliferation has been demonstrated by inhibitor experiments (Lee and Folk 1997). It has been shown that branched-chain saturated and unsaturated 1,7-diaminoheptane derivatives are potent inhibitors of deoxyhypusine synthase (DHS) because of their structural similarity to spermidine. One of the most potent inhibitors is 1-amino-7-guanidinoheptane $\left(\mathrm{GC}_{7}\right)$. Wang et al. (2001) showed that senescence-induced cDNAs encoding deoxyhypusine synthases from tomato play a role in programmed cell death.

It will be an important issue of the future to elucidate the function of the $d h s$ gene in the cell cycle of $P$. falciparum. Recently, the occurrence of homospermidine in an in vitro culture of $P$. falciparum strain NF54 was proven by GC/MS (Kaiser et al. 2001). Since homospermidine can be formed either by deoxyhy- pusine synthase or homospermidine synthase in plants (Kaiser et al. 1999, Ober and Hartmann 1999a, b) (Fig. 2 ), it still remains an open question whether a separate hss locus exists in P. falciparum. Studies on the isolation of the hss gene from Plasmodium species are currently in progress.

So far there has been no analytical proof for the occurrence of hypusine in $P$. falciparum since the concentration of hypusine in an in vitro culture is below the limit of detection. However, deoxyhypusine synthase will be a valuable target for chemotherapy because of its structural diversity to the human enzyme.

A potential drug target might also be eukaryotic translation initiation factor eIF5A. It has recently been shown that hypusinylation modulates eIF5A activity (Caraglia et al. 2001). Different functions are attributed to this protein: i) eIF5A functions as a nuclear cytoplasmic shuttle protein for certain mRNAs with low translational efficiency (Bevec and Hauber 1997), ii) eIF5A plays a role in cell growth and differentiation through polyamine-dependent post-translational modification, and iii) eIF5A is a substrate of transglutaminases (TGase) (EC 2.3.2.13) which are involved in apoptosis of cancer cells. Onset of apoptosis requires reduced eIF5A activity (Caraglia et al. 1997). Until now, an eIF5A cDNA sequence has not been published from $P$. falciparum. The first eIF5A encoding sequence was obtained from Leishmania infantum (Couvreur B. 2000, Laboratory of Applied Genetics, Belgium, un-published document) showing significant homology to eIF5A cDNA sequences from various organisms.

To understand the development of malaria and to combat it, one has to consider the life cycle of the parasite in the mosquito and the vector itself. Polyamine research is rather inadequate for the mosquito vector Anopheles. It was shown in the past by Gillet et al. (1983) that DFMO inhibits the sporogenous cycle of the malaria parasite $P$. berghei in the mosquito vector Anopheles stephensi through a blockade of the parasite's polyamine biosynthesis. However, these experiments were not continued with other specific inhibitors targeting different regulating enzymes, e.g. spermidine synthase of the polyamine pathway of the parasite or in the mosquito. Recently the first $d h s$ coding nucleic acid sequence from Anopheles gambiae was published by the consortium sequencing the $A$. gambiae genome strain PEST in GenBank. Sequencing data from the A. gambiae genome project will probably facilitate research on spermidine biosynthesis and metabolism in the mosquito in the future.

\section{SPERMIDINE BIOSYNTHESIS AND METABOLISM IN TRYPANOSOMES}

Chagas disease, known as American trypanosomiasis, is caused by the parasitic protozoan Trypanosoma cruzi, which is transmitted by blood-sucking bugs of the subfamily Triatominae. Chagas disease in humans is 
widespread in Latin America. In the gut of the insect vector, proliferating extracellular epimastigotes replicate and differentiate into the non-dividing infective form of metacyclic trypomastigotes. Once in the bloodstream, trypomastigotes enter nucleated cells (macrophages) and differentiate into proliferative intracellular amastigotes that emerge as non-dividing trypomastigotes.

No significant ODC and ADC activities could be detected in $T$. cruzi by Ariyanayagam and Fairlamb (1997). It was assumed that the parasites instead of having their own biosynthesis take up polyamines from their environment for the synthesis of spermidine and spermine (Ariyanayagam and Fairlamb 1997). The epimastigote form of $T$. cruzi is able to synthesize homotrypanothione from (bisglutathionyl) aminopropylcadaverine and trypanothione (Hunter et al., 1994) after putrescine supplementation. Early work on ADC in $T$. cruzi was performed by Kierszenbaum (1987), showing that ADC inhibitors reduce the infection capacity of $T$. cruzi in mammalian cells. Biochemical evidence for ADC activity in T. cruzi was performed by Majunder et al. (1992). Hernandez and Schwarcz De Tarlovsky (1999) reported about the presence of significant levels of ADC activity in crude extracts of $T$. cruzi RA strain epimastigotes. The enzyme activity was inhibited by DL- $\alpha$-difluoromethylarginine and the inhibitory effect reversed by agmatine. Agmatine is formed by ADC and a precursor in the biosynthesis of putrescine (Fig. 2). However, the existence of ADC in T. cruzi is still a matter of debate. It has recently been shown that arginine suppresses apoptosis in T. cruzi (Piacenza et al. 2001). Arginine supplementation reverts the biochemical events of apoptosis, i.e., DNA fragmentation and inhibition of $\left[{ }^{3}-\mathrm{H}\right]$ thymidine incorporation, but instead activates nitric oxide synthase activity.

Persson et al. (1998) succeeded in cloning the adenosylmethionine decarboxylase gene (adometdc) from genomic DNA of T. cruzi with degenerate primers of conserved regions in the adometdc genes from different species. The sequence identity to the human homologue was only $25 \%$. The coding region of the adometdc gene was expressed in E. coli and underwent autocatalytic cleavage generating two proteins of 35 $\mathrm{kDa}$ and $9 \mathrm{kDa}$. In contrast to the human enzyme, methylglyoxal bis(guanylhydrazone) (MGBG) was a poor inhibitor of the parasite adometdc. The enzyme was weakly inhibited by spermidine and strongly by spermine. The different inhibitory profiles compared to the human enzyme might be exploited as an approach in treatment of Chagas disease.

Recent findings demonstrate that spermidine is essential for normal proliferation of trypanosomatid protozoa (González et al. 2001). The authors induced a nearly complete depletion of spermidine correlating with an arrest of cell proliferation in Crithidia fasciculata, a trypanosomatid parasite of insects, and T. cruzi transformed with a stable odc gene using a combination of DFMO and cyclohexylamine, a specific inhibitor of spermidine synthase. In all cases re-initiation of proliferation occurred only after the addition of exogenous spermidine. Based on this important result, we are expecting more information about spermidine synthase and the role of spermidine in hypusine biosynthesis in the near future. Recently a nucleic acid sequence encoding DHS from T. brucei epimastigotes has been published with significant homology to human deoxyhypusine synthase isoform a (Joe et al. 1995) and the DHS protein from Neurospora crassa (Tao and Chen 1995b). However, the fasta score of the $d h s$ gene from $T$. cruzi compared to that from $N$. crassa was $37.9 \%$ in 335 amino acids.

In contrast to T. cruzi, Trypanosoma brucei gambiense, which is transmitted by Glossina spp., is very sensitive to DFMO (Van Nieuwenhove et al. 1985). One of the reasons might be that the parasite enzyme has a long half-life, i.e., $\mathrm{t}_{1 / 2}=6$ hours (Philips et al. 1987). Secondly, DFMO causes spermidine depletion, and in consequence, the radical scavenger trypanothione (bis(glutathionyl) spermidine) which contains spermidine is not able to detoxify reactive oxygen species. Trypanosomes contain $10-15 \%$ of their total spermidine in the bound form of trypanothione.

Trypanothione is the key molecule in the defence mechanism against oxidative stress in Trypanosoma (Flohe 1998, Ludemann et al. 1998) and Leishmania (Tetaud et al. 1998). The uniqueness of this molecule makes trypanothione an attractive target in antitrypanosomal and antileishmanial drug design. Biosynthesis of trypanothione comprises the activity of glutathionylspermidine synthetase and trypanothione reductase. However, in this review we want to focus on the development of drug design against two enzymes involved in trypanothione biosynthesis, i.e., glutathionylspermidine synthetase catalyzing the formation of glutathione and the spermidine conjugate (Chen and Coward 1998) and ODC which is involved in the production of putrescine as a precursor of spermidine. Both enzymes provide the link to polyamine biosynthesis. It has been shown by Chen and Coward (1998) that an alanine-containing phosphinate analogue of glutathionylspermidine inhibits glutathionylspermidine synthetase from E. coli and C. fasciculata.

Inhibition of ODC leads to a reduction of trypanothione biosynthesis (Carrillo et al. 2000). Experiments in the past showed that DFMO reduces trypanothione levels significantly in sensitive strains of trypanosomes, but no reduction of trypanothione was observed in strains with resistance to the drug since the latter produced high levels of ornithine (Carrillo et al. 2000).

Due to the significant growth effects, caused by polyamines on the proliferation of $T$. brucei brucei, spermidine synthase was characterised in this parasite. The purified spermidine synthase from $T$. brucei brucei 
was found to be similar to enzymes from other sources (Bitonti et al. 1984). The approximate molecular size of the enzyme was determined to be $74 \mathrm{kDa}$. Spermidine synthase activity was markedly inhibited by $50 \%$ in vitro by dicyclohexylamine at a concentration of $3 \mu \mathrm{M}$ and by cyclohexylamine by $50 \%$ at a concentration of $25 \mu \mathrm{M}$. However, intraperitoneal administration of 200 mg dicyclohexylamine per kilogram twice a day for three days to mice infected with $2.5 \times 10^{5} \mathrm{~T}$. brucei brucei resulted in no change in progress of the disease and did not increase the period of survival times of the infected animals. In this context it is interesting to note that a challenge of mice with a $T$. brucei mutant blood stream form in which both copies of ODC had been knocked out led to protection against wild-type $T$. brucei expressing the same variant surface glycoprotein (Mutomba et al. 1999). Presumably, these results are due to immunisation with a $T$. brucei mutant. However, it was shown that ODC has an essential role in the process of infection since the $T$. brucei mutant strain was unable to establish an infection in mice. The Trypanosoma ODC double mutant did not express odc mRNA and ODC enzyme activity and was unaffected by the inhibitor DFMO (Li et al. 1998).

Bacchi and co-workers (1980) have found that DFMO was able to cure T. brucei acute infections in mice and that it could be successfully employed against human sleeping sickness. The selective therapeutic activity of the drug on the ODC of the parasite has been partially attributed to the metabolic stability of trypanosomal ODC compared to the high turnover of the human enzyme (Phillips et al. 1987). The slow turnover rate of trypanosomal ODC is due to the absence of PEST sequences near the $\mathrm{C}$-terminus of the corresponding human enzyme, which has been postulated as a signal for rapid degradation (Ghoda et al. 1990).

Recently, Carrillo et al. (2000) investigated the regulatory mechanisms for drug tolerance of DFMO in $T$. cruzi transformed with the odc gene from C. fasciculata and in Leishmania mexicana. Resistance in C. fasciculata and Phytomonas, a plant parasite, was investigated. Drug tolerance was caused by a rapid turnover of ODC in transformed T. cruzi and in L. mexicana. A determination of polyamine pools in ODC-transformed T. cruzi and L. mexicana showed that DFMO caused a significant decrease in putrescine and spermidine. Spermidine depletion was higher in parasites containing an ODC with a slow turnover indicating that spermidine might decrease below critical levels, needed to maintain trypanothione concentrations for normal cell proliferation (Carrillo et al. 2000).

\section{THE ROLE OF SPERMIDINE IN LEISHMANIA}

The analysis of ribosomal RNA from various species of Trypanosoma and Leishmania indicate that both trypanosomatid genera are closely related. Visceral leishmaniasis known as "Kala Azar" is found in Asia and Africa, while mucosal and cutaneous leishmaniases, the "oriental sore" are more prominent in the Americas. Both types of leishmaniases are transmitted by female sandflies of the genera Phlebotomus (Leishmania $d$. donovani, Leishmania $d$. infantum) and Lutzomyia (Leishmania $d$. chagasi). The parasite exhibits a digenetic life cycle with the promastigote residing in the phlebotomine sandfly vector and the intracellular amastigote propagating within the phagolysosome of mammalian macrophages.

Since there is an increasing resistance against the usual therapeutic agents like polyvalent antimonials, an extended search for improved medicinals has started. One strategy might be the exploitation of inhibitors against biosynthetic enzymes of the polyamine pathway or to develop inhibitors against polyamine transporters.

Promastigotes that are present in the sandfly can be easily cultivated in vitro. It has been reported that promastigotes contain putrescine and spermidine as the major polyamines (Bachrach et al. 1979). In feeding experiments with $\left[{ }^{14} \mathrm{C}\right]$-putrescine the authors showed that the diamine is taken up and converted to spermidine. These results suggested that spermidine biosynthesis takes place in the parasite. It was proven by Bachrach et al. (1979) that amastigotes, developed in macrophages of infected mouse skin, showed significantly increased levels of putrescine and spermidine as well as of ODC. The levels of the enzyme and the polyamines in the skin were suggested as possible markers to test the efficacy of chemotherapeutic agents.

The ODC turned out to be cytostatic in leishmanial promastigotes in polyamine-deficient medium. However, no inhibition by DFMO was observed when putrescine and spermidine were present in the medium (González et al. 1991).

Extracts of L. mexicana contained an active ODC (Hanson et al. 1992) with unusual properties. The open reading frame encodes for a protein of 707 amino acids and has an extra $\mathrm{NH}_{2}$ terminal extension of 200 amino acids and lacks the PEST region at the $\mathrm{C}$-terminus.

Cloning of the genes involved in spermidine biosynthesis has been successfully performed in Leishmania donovani. The construction of an adometdc doubletargeted gene replacement mutant shows that adometdc is an essential gene in $L$. donovani promastigotes (Roberts et al. 2002b). The adometdc mutant could only be rescued by spermidine supplementation of the culture medium or by an episomal copy of adometdc. Polyamine-starved adometdc parasites show decreased levels of spermidine and glutathione.

The adometdc gene from $L$. infantum promastigotes was cloned and characterised by Taladriz et al. (2002). The authors showed that the gene has a close phylogenetic relationship to T. cruzi $(83 \%)$. However, the relationship to T. brucei $(76 \%)$ is less and it drastically fell with respect to mammalians (62\%) and plants (Oryza sativa, 47\%). A significant transcription of the gene in the cell cycle of the parasite was not observed. 
An increase in mRNA production was stage-specific detectable in promastigotes preferentially in the infective phase of the parasite against macrophage action.

Spermidine synthase from $L$. donovani has been cloned and sequenced (Roberts et al. 2002a). The $L$. donovani spermidine synthase gene (spds) is present as a single copy gene in the genome exhibiting $56 \%$ amino acid identity to its human counterpart. The authors created a $\Delta$ spsyn knockout strain of $L$. donovani that was strictly auxotrophic for spermidine and was unable to convert putrescine into spermidine. Overall, it was shown that the spds gene is an essential gene in $L$. donovani promastigotes and is crucial for cell proliferation. Since Leishmania, like trypanosomes, contain trypanothione, a spermidine-containing thiol, spermidine depletion led to a reduction of trypanothione whereas the glutathione pool increased approximately four-fold. In arsenite-resistant Leishmania it was observed that levels of trypanothione and the polyamines putrescine and spermidine increased due to an overexpression of ornithine decarboxylase which was not caused by gene amplification (Haimur et al. 1999).

Two sequences encoding the spermidine-metabolizing enzymes deoxyhypusine synthase (Akopyants et al. 2001) and homospermidine synthase (Ivens et al. 1998) have been isolated from $L$. major and published in GenBank. The amino acid sequence of homospermidine synthase from $L$. major shows a striking homology to the bacterial gene from Rhodopseudomonas viridis (Tholl et al. 1996) and to the viral gene PBCV-1 infecting a chlorella green alga (Kaiser et al. 1999), while the $d h s$ gene from $L$. major shows significant homology to $d h \mathrm{~s}$ sequences from different species. It will be an interesting issue for the future to delineate the function of both genes in Leishmania. Consequently, it has to be discussed whether the triamine homospermidine might substitute for spermidine under certain physiological conditions. This would explain the occurrence of both genes in the parasite. Overall, both gene products might be new valuable targets in chemotherapy.

Recently two different specific polyamine transporters for spermidine and putrescine have been characterised in promastigotes of L. mexicana and L. donovani and in amastigotes of L. mexicana (Basselin et al. 2000). However, both genes have not been identified so far. Both transporters are differently expressed in promastigotes and amastigotes. Pentamidine is a noncompetitive inhibitor for both transporters. The fact that these uptake systems were inhibited by protonophores and $\mathrm{H}^{+}$-ATPase inhibitors delineates a new strategy for drug development against both transport systems. To date, none of the transporter genes has been identified.

\section{SPERMIDINE METABOLISM IN NEMATODES}

Research on hypusine in parasitic nematodes is redundant. Until now, there have been no database reports on deoxyhypusine synthase and homospermidine synthase in parasitic nematodes. So far the biosynthetic pathway of parasitic nematodes has been elucidated up to spermidine. Parasitic nematodes appear to lack ODC and are mainly dependent on polyamine uptake and interconversion for their supply of polyamines (Walter 1988). It is remarkable that the cDNA for ODC has been cloned from the free-living nematode Panagrellus redivivus (Besser et al. 1995), which resembles parasitic nematodes in overall structure and development, to study polyamines at the biochemical and molecular level. The sequence of the isolated odc gene shows $32 \%$ amino acid identity to odc genes from invertebrates and lacks the PEST sequence. It is suggested from the presence of a conserved Glycin379 that the protein is an enzymatically active homodimer. Although it is not possible to demonstrate ODC activity in human and animal filarial parasites it would be informative to compare the gene structure and mRNA expression of ODC between a free-living nematode and a parasitic nematode. The genetic information obtained from the odc gene of $P$. redivivus might be a model which leads to an understanding of adaptation to parasitism in case of the apparent lack of ODC in parasitic nematodes.

A polyamine oxidase, which is involved in polyamine interconversion, beside spermidine/spermine acetylase (SSAT) as the rate-limiting enzyme, has been shown to be inhibited by haloallylamines in Ascaris suum, an intestinal nematode, while simultaneously spermine concentrations raised about 200\% (Müller et al. 1996).

Polyamine interconversion has been intensively studied in A. suum and in Onchocerca volvulus causing river blindness in tropical West Africa (Wittich and Walter 1990). Putrescine-N-acetyltransferase from both parasitic nematodes could be inhibited by the drug berenil $^{\circledR}$. Both nematode enzymes preferentially acetylate putrescine and histamine, while serotonine and dopamine were not accepted. Putrescine-N-acetyl-transferase is discussed as a regulatory step in the degradation of excessive polyamines via polyamine oxidase to putrescine. Putrescine can either be channelled into the de novo synthesis of spermidine and spermine or its acetylated derivative is a suitable transport product for excretion. Since polyamine metabolism in filarial parasites displays unusual features compared to the situation in the host, the pathway has potential in chemotherapy.

The interaction between the polyamines spermidine, spermine and the drug suramin ${ }^{\circledR}$, the polysulphonated naphthylamine derivative of urea, has been demonstrated for antifilarial DNA from Setaria cervi (Pandya et al. 1997), which is extremely AT rich. While the polyamines spermine and spermidine stabilized the secondary structure of the filarial DNA, a destabilizing effect of filarial DNA was observed for suramin ${ }^{\circledR}$. The 
destabilizing effect was accompanied by a decrease in melting temperature, condensation, and $\mathrm{B}$ to $\mathrm{Z}$ transition. Destabilisation was not observed for calf thymus DNA. Thus destabilisation of DNA together with atypical polyamine metabolism between the host and the parasite might be a novel strategy for the design of antifilarial drugs.

The role of polyamines in development of parasitic nematodes has not been under investigation. Developmental studies on the effect of spermidine have been performed in Caenorhabditis elegans (Macrae et al. 1998). The authors showed that odc-1 worms, which were null mutants obtained by targeted gene disruption, had a slight reduction in breed size when grown in complex medium. However, a strong phenotype was observed when mutant animals developed under polyamine deficiency at the L1 larval stage into adult hermaphrodites resulting in the production of very few or no eggs. In contrast, if mutant larvae at the L4 stage were transferred into polyamine-deficient medium, $90 \%$ of the eggs yielded embryos that developed normally, but arrested at early stage L3. Supplementation of the polyamine-deficient medium of the odc-mutant worm with spermidine overrides the developmental requirement for ODC activity. These results suggest that polyamines are required at early stages of development, in oogenesis and embryogenesis.

\section{THE FUNCTION OF SPERMIDINE IN BACTERIA, VIRUSES AND PLANTS - A COMPARISON TO PARASITIC PROTOZOA}

In contrast to the situation in plants, fungi and parasitic protozoa, spermidine is not essential for growth in Escherichia coli. Hafner et al. (1979) showed that an $E$. coli triple mutant with deletion mutations in the speA (arginine decarboxylase), speC (ornithine decarboxylase) and speD (adenosylmethionine decarboxylase) genes grew indefinitely in the absence of polyamines. Similar results were obtained with an $E$. coli speE (spermidine synthase) and speD (adenosylmethionine decarboxylase) mutant (Vogel and Bonner 1956) which synthesizes no spermidine and shows $55 \%$ of the wild-type growth rate. However, there are some Eubacteria that lack spermidine and use other polyamines. For example, in Methanococcus the uncommon triamine homospermidine and putrescine are the major polyamines while spermidine constitutes only $0.6 \%$ of the polyamine pool (Busse and Auling 1988). Experiments performed with an $E$. coli deletion mutant blocked in the spermidine synthase gene showed that the impaired growth rate of the mutant could be restored to wild-type level by supplementation with spermidine and related polyamines (Tholl et al. 1998). Overall, the mutant was complemented by heterologous expression with the hss gene from Rhodopseudomonas viridis (Tholl et al. 1996). These results suggest that sper- midine and homospermidine are functionally interchangeable in some bacterial species.

Although hypusine is not present in bacterial samples, it is remarkable that the bacterial elongation factor EF-P is related to archaeal/eukaryotic initiation factor eIF5A as reported by Kyrpides and Woese (1998). Whereas bacterial and eukaryotic sequences display an average sequence identity of $20 \%$, the alignment with either the bacterial or the eukaryotic/ archaeal initiation factor highlights their relatedness. Most notably, the highest density of sequence conservation is found in the vicinity of the minimal region of the protein that must be conserved for hypusine-lysine conversion to occur. The most striking difference is the well-conserved C-terminal section in EF-P from different bacterial species, which is absent in both archaeal and eukaryotic species.

The biological function of spermidine in viruses is still unknown. A simple hypothesis of the past was that polyamines might participate in viral replication by neutralizing viral nucleates, but there was no biochemical and molecular proof for the biosynthesis of viral polyamines. The first proof for a viral biosynthesis of polyamines was obtained from the double-stranded virus PBCV-1 that infects a unicellular, Chlorella-like green alga. From a screen of different databases it was obvious that the 518-residue protein encoded by the PBCV-1 ORF A237R has a 34\% amino acid identity to the 477-residue Rhodopseudomonas viridis HSS enzyme. The cloned and expressed viral gene encoded a functional active HSS (Kaiser et al. 1999). In the meantime, ODC has been isolated and sequenced from Chlorella virus PBCV-1 (Van Etten et al. 2002, University of Lincoln, Nebraska, unpublished document). These results confirm that a polyamine pathway from putrescine to homospermidine exists in the virus.

The function of the triamine homospermidine present in viral capsids of PBCV-1 is still unknown. It was shown from the data obtained from polyamine analysis that the number of polyamines per PBCV-1 virion is so low that they could neutralise only $0.2 \%$ of the virus phosphate residues. However, the viral hss gene is widely spread among 42 different Chlorella viruses tested (Kaiser et al. 1999). Transcription patterns showed that the viral hss gene is induced late in viral replication because DNA synthesis started 60 minutes post infection. The fact that the putrescine concentration increased two-fold during infection while the content of all the other polyamines decreased suggests the question of the occurrence of two different biochemical pathways in the plant and the virus. It is likely that the Chlorella host synthesizes homospermidine under catalysis of DHS while the virus synthesizes homospermidine strictly from two molecules of putrescine under catalysis of HSS. Cloning the $d h s$ gene from the host Chlorella will show whether homospermidine will be formed by DHS. 


\section{HYPUSINE FORMATION IN FUNGI}

Most of the early studies on hypusine biosynthesis were performed in the yeast Saccharomyces cerevisiae and the fungus Neurospora crassa. Kang et al. (1995) cloned deoxyhypusine synthase from $S$. cerevisiae using primers that perfectly matched to five tryptic peptides obtained from the purified enzyme from rat testis and expressed the protein in E. coli. The mass of the polypeptide was determined to be $43 \mathrm{kDa}$. The enzyme exists as a tetramer with significant homology to the enzyme from human, rat and Neurospora. Independently, Abid et al. (1997) purified deoxyhypusine synthase from the yeast Saccharomyces carlsbergensis. Site-directed mutagenesis of $\mathrm{Lys}^{287}$ and $\mathrm{Lys}^{329}$ of the enzyme was shown to be essential for cell viability and growth of S. cerevisiae (Park et al. 1998). Kang and Chung (1999) demonstrated deoxyhypusine synthase to be post-translationally modified by protein kinase $\mathrm{C}$ in vitro. Most notably the authors showed that 15 amino acid residues of the $\mathrm{N}$-terminus are not required for enzymatic activity.

Presumably one of the functions of eIF5A in yeast can be attributed to mRNA turnover as results obtained from a temperature sensitive point mutation of an eIF5A yeast mutant suggest (Zuk and Jacobsen 1998).

Deoxyhypusine synthase from $N$. crassa was first purified to homogenity by substrate elution chromatography by Tao and Chen (1995a) before it was finally cloned (Tao and Chen 1995b). Deoxyhypusine synthase from $N$. crassa encodes a protein of $40 \mathrm{kDa}$ showing $69 \%$ amino acid identity to the $S$. cerevisiae enzyme.

Polyamine metabolism in phytopathogenic fungi has attracted attention due to the demonstration that specific inhibition of polyamine biosynthesis can lead to a control of fungal plant disease (Pieckenstain et al. 2001). It has been shown that most of these fungi lack the ADC pathway. Hence, it has been an interesting observation that DFMO and DFMA inhibited mycelial growth, e.g., in Sclerotinia sclerotiorum, while methylglyoxalbis-[guanyl]hydrazone, an inhibitor of SAMDC, exerted no effect. Inhibition with cyclohexylamine, an inhibitor of spermidine synthase, affected sclerotial formation.

It will be a question of time to elucidate the biosynthesis of hypusine and homospermidine in phytopathogenic fungi and to unravel their function in pathogenesis. In particular, inhibition of both enzymes might be of considerable interest for sclerotial formation and the formation of ascospores.

\section{THE ROLE OF POLYAMINES IN PLANT GROWTH AND DEVELOPMENT}

Although putrescine was believed to be formed in animals only by decarboxylation catalyzed by ODC, recent results have shown that there are distinct pathways in mammals which lead to putrescine.
Mammalian agmatinase, which forms putrescine from agmatine, has recently been cloned from human (Iyer et al. 2002) and shares significant homology of their substrate-binding domains with agmatinase from $E$. coli and arginases I and II from human. Most notably, agmatinase from human is induced during hepatitis B virus infection, suggesting its role in the pathophysiology of the disease (Mistry et al. 2002). Recent reports about characterisation of $\mathrm{ADC}$ in rat brain prove that a separate biosynthetic pathway from arginine to putrescine exists in mammalian cells (Regunathan and Reis 2000). While mammalian ODC is expressed at low levels in all tissues except testis and cytosol, ADC is preferentially expressed in aorta and associated with mitochondrial membranes.

Higher plants share with bacteria the coexistence of two different pathways for putrescine biosynthesis, i.e., one directly via ODC and the other through a series of intermediates (agmatine, N-carbamoylputrescine) (Fig. 2) following action of ADC (Tiburcio et al. 1990). In plants polyamines play a role in cell division, growth and development, macromolecular synthesis, hormonemediated responses and as anti-senescense agents (Gosh 1999). Since most of the genes encoding polyamine biosynthetic enzymes from ornithine/arginine to spermine have been isolated in plants, transgenic plants and mutants have been used to study their role in plant growth and development.

One of the developmental studies was the constitutive expression of S-adenosylmethionine decarboxylase in potato plants. Expression of SAMDC in sense orientation turned out to be lethal to plants (Kumar et al. 1996). In these transgenic sense plants putrescine levels were reduced whereas the spermidine content was three times higher than in control plants. The antisense plants, however, developed a number of abnormal phenotypes with highly branched stems, short internodes, small leaves and inhibited growth.

An altered phenotype in transgenic tobacco plants was also observed after expression of arginine decarboxylase from Avena sativa under the control of a tetracycline-inducible promoter (Masgrau et al. 1997). The severity of the altered phenotype correlated with high levels of endogenous putrescine. The phenotype was characterised by short internodes, thin stems and leaves, leaf chlorosis and reduced growth. The detrimental effects that were observed only in the vegetative stage after induction of arginine decarboxylase emphasise the role of specific polyamines in certain developmental stages.

The biological effects of spermidine are wide ranging in plants. Spermidine and cadaverine were both found to increase in seeds of Pisum sativum during germination (Lin et al. 1984). The effect on root formation and growth has been reported. Spermidine was highest in the apices, decreasing with cell elongation (Shen and Galston 1985). The process of flowering is accompanied 


\begin{tabular}{lll}
\hline Polyamine precursors & Alkaloids & Substance \\
\hline Putrescine & tobacco alkaloids & $\begin{array}{l}\text { nicotine }^{\mathrm{a}} \text {, nornicotine } \\
\text { tropane alkaloids }\end{array}$ \\
$\begin{array}{l}\text { hyoscyamine } \\
\text { Homospermidine }\end{array}$ & $\begin{array}{l}\text { pyrrolizidine alkaloids } \\
\text { retronecine }\end{array}$ \\
Cadaverine, spermidine & quinolizidine & $(-)-$ spartein $^{\mathrm{d}}$ \\
\hline
\end{tabular}

a)<smiles>CN1CCCC1(c1cccnc1)c1cccnc1</smiles>

b)<smiles>[R]C(=O)C(CO)c1ccccc1</smiles>

d)<smiles>[R]CC1CCC(OC)C2CCC1N2C</smiles>

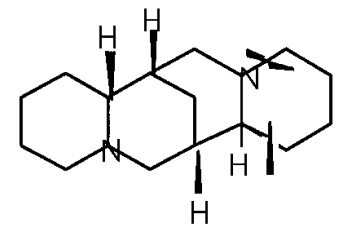

Fig. 3. Table of polyamines with precursor function in the biosynthesis of alkaloids and the structure of each alkaloid representative. a) nicotine, b) hyoscyamine, c) retronecin, d) spartein.

by a rapid increase of conjugated spermidine in tobacco flower buds (Malmberg et al. 1994). Hydroxycinnamoyl derivatives mainly from putrescine and spermidine were first detected in tobacco cultures and accumulated after infection of whole tobacco plants with tobacco mosaic virus. It was reported by Martin et al. (1985) that hydroxycinnamoyl putrescine promotes callus formation of tobacco leaf discs but inhibits bud formation.

\section{PUTRESCINE AND HOMOSPERMIDINE ARE IMPORTANT PRECURSORS IN THE BIOSYNTHESIS OF PLANT ALKALOIDS}

Alkaloids constitute, as nitrogenous secondary metabolites, the active basic principle of flowering plants. Putrescine is an important precursor in the biosynthesis of the pyrrolidine alkaloid nicotine in Nicotiana tabacum (Solanaceae) and of the tropane alkaloid hyoscyamine in Hyoscyamus niger (Solanaceae) (summarized in Gosh 2000) (Fig. 3).

The carboskeleton of the necine base of pyrrolizidine alkaloids is exclusively derived from homospermidine (Ober and Hartmann 2000) (Fig. 3). Since plant homospermidine synthase is strictly specific for the production of alkaloids and recruits from deoxyhypusine synthase (Kaiser 1999), it seems possible that HSS has evolved by evolutionary change of function (Ober and Hartmann 2000). Until now, hypusine biosynthesis has been studied in N. tabacum (Ober and Hartmann 1999a), Lycopersicon esculentum (Solana- ceae) (Wang et al. 2001), and Senecio vernalis (Asteraceae) (Ober and Hartmann 1999b). Expression of the bacterial hss gene from Rhodopseudomonas viridis in transgenic tobacco plants (Kaiser et al. 2002) leads to a significantly decreased content of free spermidine and a delay in development. Deoxyhypusine synthases from different species share significant homology. Most notable is the occurrence of DHS isoforms in $L$. esculentum, suggesting a possible developmental and tissue specific expression. Of particular interest is the finding that senescence-induced DHS and eIF5A in tomato tissues may facilitate the translation of mRNA species required for programmed cell death (Wang et al. 2001).

\section{CONClusions}

From the current status of work it is evident that spermidine is absolutely necessary for cell proliferation in parasitic protozoa, plants and fungi. Spermidine interacts with nucleic acids and membrane proteins. Among these essential functions of spermidine may be the formation of hypusine and homospermidine and thus the link between polyamine biosynthesis and protein biosynthesis. Possibly both spermidine-metabolizing enzymes might be novel drug targets for antiparasite therapy (Fig. 4) if these metabolites have been demonstrated to be important. The current status of spermidine research in Plasmodium falciparum is summarized in Fig. 4. 


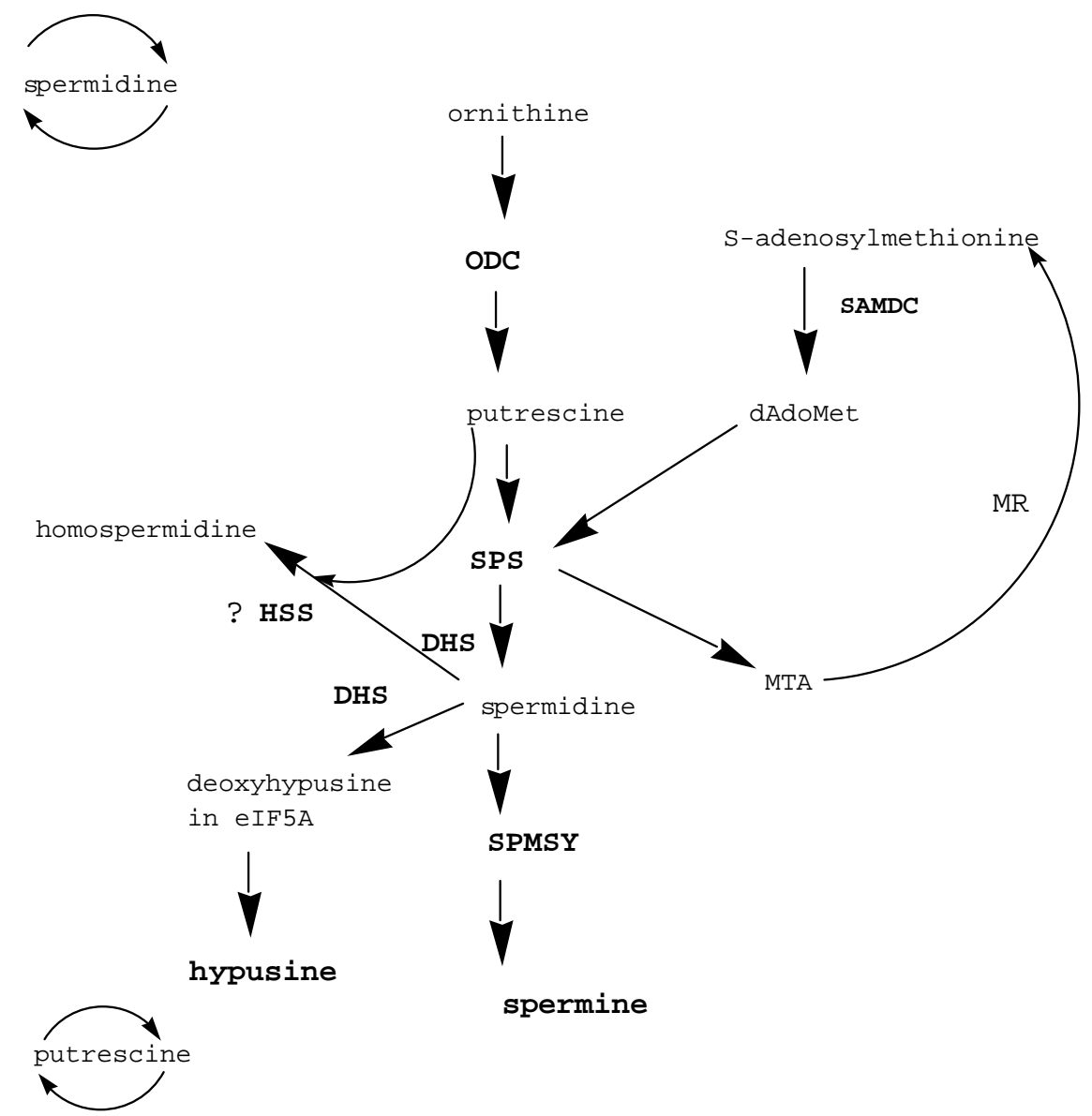

Fig. 4. Polyamine biosynthesis and metabolism in Plasmodium falciparum. The biosynthesis of putrescine and decarboxylated S-adenosylmethionine is catalyzed by a bifunctional enzyme ornithine (ODC)/S-adenosylmethionine decarboxylase (SAMDC) in $P$. falciparum. Spermidine synthase (SPDS) catalyzes the reaction from putrescine and decarboxylated S-adenosylmethionine to spermidine. The existence of spermine in P. falciparum is still a matter of debate. A characterisation of the enzyme spermine synthase (SPMSY) was not successful. Spermidine is a very important substrate of the enzyme deoxyhypusine synthase (DHS), which is ubiquitous in all eukaryotes. Deoxyhypusine synthase catalyzes the first step in hypusinylation of a eukaryotic translation initiation factor eIF5A. Sequencing data obtained from the malaria genome project suggest the occurrence of the $d h s$ gene in the parasite. The triamine homospermidine can be formed by DHS or by HSS from spermidine and putrescine. Distinct transporter systems for putrescine and spermidine have been described. Abbreviations: MTA - methylthioadenosine, MR methionine recycling pathway.

\section{REFERENCES}

ABBRUZZESE A. 1988: Developmental pattern for deoxyhypusine hydroxylase in rat brain. J. Neurochem. 50: 695699.

ABBRUZESE A., HAUSKE-ABEL H.M., PARK M.H., HENKE S., FOLK J.E. 1991: The active site of deoxyhypusyl hydroxylase: used catechol peptides and their component chalator and peptide moieties as molecular probes. Biochem. Biophys. Acta 1077: 159-166.

ABBRUZZESE A., PARK M.E., FOLK J.E. 1986: Deoxyhypusine hydroxylase from rat testis. J. Biol. Chem. 261: 3085-3089.

ABID M.R., SASAKI K., TITANI K., MIYAZAKI M. 1997: Biochemical and immunological characterization of deoxyhypusine synthase from the yeast Saccharomyces carlsbergensis. J. Biochem. 121: 769-778.
AKOPYANTS N.S., CLIFTON S.W., MARTIN J., PAPE D., WYLIE T., LI L., KISSINGER J., ROOS D.S., MARRA M., HILLIER L., CHINWALLA A., BLISTANI A., SCHMITT A., PERSON B., THEISING B., RITTER E., RANKE I., BENNET J., COLE R., UNDERWOOD K., CORDENOS M., GIBBONS M., HERVEY M., McCANN R., TSAGORISKVILLI R., WILLIAMS T., JACKSON Y., BOWERS Y., SWALLER T., WATERSTON R., WILSON R., BEVERLY S.M. 2001: A survey of the Leishmania Friedlin strain V1 genome by shotgun sequencing: a resource for DNA microarrays and expression profiling. Mol. Biochem. Parasitol. 113: 337340.

AMES B.N., DUBIN D.T. 1960: The role of polyamines in the neutralization of bacteriophage deoxyribonucleic acid. J. Biol. Chem. 235: 769-775. 
ANDRUS L., SZABO P., GRADY R.W., HANAUSKE A.R., HUIMA-BYRON T., SLOWINSKA B., ZAGULSKA S., HANAUSKE-ABEL H.M. 1998: Antiretroviral effects of deoxyhypusyl hydroxylase inhibitors - A hypusinedependent host cell mechanism for replication of human immunodeficiency virus type 1 (HIV-1). Biochem. Pharmacol. 55: 1807-1818.

ARIYANAYAGAM M.R., FAIRLAMB A.H. 1997: Diamine auxotrophy may be a universal feature of Trypanosoma cruzi epimastigotes. Mol. Biochem. Parasitol. 84: 111121.

ASSARAF Y.G., ABU-ELHEIGA L., SPIRA D.T., DESSER H., BACHRACH U. 1987: Effect of polyamine depletion on macromolecular synthesis of the malaria parasite, Plasmodium falciparum, cultured in human erythrocytes. Biochem. J. 242: 221-226.

ASSARAF Y.G., GOLENSER J., SPIRA D.T., BACHRACH U. 1984: Polyamine levels and the activity of their biosynthetic enzymes in human erythrocytes infected with the malarial parasite Plasmodium falciparum. Biochem. J. 222: 815-819.

BACCHI C.J., NATHAN H.C., HUTNER S.H., McCANN P.P., SJOERDSMA A. 1980: Polyamine metabolism: a potential therapeutic target in trypanosomes. Science 210: 332-334.

BACHRACH U., ABU-ELHEIGA L. 1990: Effect of polyamines on the activity of malarial alpha-like DNA polymerase. Eur. J. Biochem. 191: 633-637.

BACHRACH U., BREM S., WERTMAN S.B., SCHNUR L.F., EL-ON J., GREENBLATT C.L. 1979: Leishmania spp.: cellular levels and synthesis of polyamines during growth cycles. Exp. Parasitol. 48: 464-470.

BASSELIN M., COOMBS G.H., BARRETT M.P. 2000: Putrescine and spermidine transport in Leishmania. Mol. Biochem. Parasitol. 109: 37-46.

BESSER H.V., NIEMANN G., DOMDEY B., WALTER R.D. 1995: Molecular cloning and characterization of ornithine decarboxylase cDNA of the nematode Panagrellus redivivus. Biochem. J. 308: 635-640.

BEVEC D., HAUBER J. 1997: Eukaryotic initiation factor 5A activity and HIV-1 Rev function. Biol. Sig. 6: 124-133.

BITONTI A.J., KELLY S.E., McCANN P.P. 1984: Characterization of spermidine synthase from Trypanosoma brucei brucei. Mol. Biochem. Parasitol. 13: 21-28.

BUSSE J., AULING G. 1988: Polyamine pattern as a chemotaxonomic marker within the Proteobacteria. Syst. Appl. Microbiol. 11: 1-8.

CARAGLIA M., MARRA M., GIUBERTI G., D'ALLESSANDRO A.M., BUDILLON A., del PRETE S., LENTINI A., BENINATI S., ABBRUZZESE A. 2001: The role of eukaryotic initiation factor $5 \mathrm{~A}$ in control of cell proliferation and apoptosis. Amino Acids 20: 91-104.

CARAGLIA M., PASSEGGIO A., BENINATI S., LEARDI A., NICOLINI L., IMPROTA S., PINTO A., BIANCO A.R., TAGLIAFERRI P., ABBRUZZESE A. 1997: Interferon $\alpha 2$ recombinant and epidermal growth factor modulate proliferation and hypusine synthesis in human epidermoid cancer KB cells. Biochem. J. 324: 737-741.

CARRILlO C., CEJAS S., CORTES M., CERIANI C., HUBER A., GONZÁLEZ N., ALGRANATI I.D. 2000:
Sensitivity of trypanosomatid protozoa to DFMO and metabolic turnover of ornithine decarboxylase. Biochem. Biophys. Res. Commun. 279: 663-668.

CHEN S., COWARD J.K. 1998: Investigations on new strategies for the facile synthesis of polyfunctionalized phosphinates: phosphinopeptide analogues of glutathionylspermidine. J. Org. Chem. 63: 502-509.

FLOHE L. 1998: The Achilles' heel of trypanosomatids: trypanothione-mediated hydroperoxide metabolism. Biofactors 8: 87-91.

GHODA L., PHILLIPS M.A., BASS K.E., WANG C.C., COFFINO P. 1990: Trypanosoma ornithine decarboxylase is stable because it lacks sequences found in the carboxyl terminus of the mouse enzyme which target the latter for intracellular degradation. J. Biol. Chem. 265: 1182311826.

GILlET J.M., CHARLIER J., BONE G., MULAMBA P.L. 1983: Plasmodium berghei: inhibition of the sporogonous cycle by $\alpha$-difluoromethylornithine. Exp. Parasitol. 56: 190-193.

GONZÁLEZ N.S., HUBER A., ALGRANATI I.D. 2001: Spermidine is essential for normal proliferation of trypanosomatid protozoa. FEBS Lett. 508: 323-326.

GONZÁLEZ N.S., SÁNCHEZ C.P., SFERCO L., ALGRANATI I.D. 1991: Differential regulation of putrescine uptake in Trypanosoma cruzi and other trypanosomatids. Biochem. Biophys. Res. Commun. 180: 797804.

GOSH B. 1999: Polyamines in the regulation of plant senescence. J. Plant Biol. 26: 129-134.

GOSH B. 2000: Polyamines and plant alkaloids. Indian J. Exp. Biol. 38: 1086-1091.

HAFNER E.W., TABOR C.W., TABOR H. 1979: Mutants of Escherichia coli that do not contain 1,4 diaminobutane (putrescine) or spermidine. J. Biol. Chem. 254: 1241912426.

HAIMUR A., GUIMOND C., PILOTE S., MUKHOPADHYAY R., ROSEN B.R., POULIN R., OUELLETTE M. 1999: Elevated levels of polyamines and trypanothione resulting from overexpressing of the ornithine decarboxylase gene in arsenite-resistant Leishmania. Mol. Microbiol. 34: 726-735.

HAMASAKI-KATAGIRI N., TABOR C.W., TABOR H. 1997: Spermidine biosynthesis in Saccharomyces cerevisiae: polyamine requirement of a null mutant of the spe3 gene (spermidine synthase). Gene 187: 35-43.

HANSON S., ADELMAN J., ULLMAN B. 1992: Amplification and molecular cloning of the ornithine decarboxylase gene of Leishmania donovani. J. Biol. Chem. 267: 23502359.

HASHIMOTO T., TAMAKI K., SUZUKI K., YAMADA Y. 1998: Molecular cloning of plant spermidine synthases. Plant Cell Physiol. 39: 73-79.

HERNANDEZ S., SCHWARCZ De TARLOVSKY M. 1999: Arginine decarboxylase in Trypanosoma cruzi, characteristics and kinetic properties. Cell. Mol. Biol. 45: 383-391.

HIBASAMI H., TSUKADA T., NISHIGUCHI Y., SAKURAI M., SHIRAKAWA S., NAKASHIMA K. 1994: Remarkable activation of polyamine biosynthesis in hematopoiesis and hyperplasia of spleen in mice with 
hemolytic anemia caused by infection with Plasmodium berghei. Int. J. Parasitol. 24: 213-217.

HUNTER K.J., LEQUESNE S.A., FAIRLAMB A.H. 1994: Identification and biosynthesis of $\mathrm{N}^{1}, \mathrm{~N}^{9}$-bis(glutathionyl)aminopropylcadaverine (homotrypanothione) in Trypanosoma cruzi. Eur. J. Biochem. 226: 1019-1027.

IVENS A.C., LEWIS S.M., BAGHERZADEH A., ZHANG L., CHAN H.M., SMITH D.F. 1998: A physical map of the Leishmania major Friedlin genome. Gen. Res. 8: 135145.

IYER R.K., KIM H.K., TSOA R.W., GRODY W.W., CEDERBAUM S.D. 2002: Cloning and characterization of human agmatinase. Mol. Genet. Metabolism 75: 209218.

JENKINS Z.A., HAAG P.G., JOHANSSON H.E. 2001: Human eIF5A2 on chromosome $3 \mathrm{q} 25-\mathrm{q} 27$ is a phylogenetically conserved vertebrate variant of eukaryotic translation initiation factor $5 \mathrm{~A}$ with tissue-specific expression. Genomics 71: 101-109.

JOE Y.A., WOLFF E.C., PARK M.H. 1995: Cloning and expression of human deoxyhypusinesynthase cDNA. Structure-function studies with the recombinant enzyme and mutant proteins. J. Biol. Chem. 270: 22386-22392.

KAISER A. 1999: Cloning and expression of a cDNA encoding homospermidine synthase from Senecio vulgaris (Asteraceae) in Escherichia coli. Plant J. 19: 195-201.

KAISER A., GOTTWALD A., WIERSCH C., LINDENTHAL B., MAIER W., SEITZ H.M. 2001: Effect of drugs inhibiting spermidine biosynthesis and metabolism on the in vitro development of Plasmodium falciparum. Parasitol. Res. 87: 963-972.

KAISER A., SELL S., HEHL R. 2002: Heterologous expression of a bacterial homospermidine synthase gene in transgenic tobacco: effects on the polyamine pathway. Arch. Pharm. 4: 143-151.

KAISER A., VOLLMERT M., THOLL D., GRAVES M.V., GURNON J.R., XING W.M., LISEC A.D., NICKERSON K.W., Van ETTEN J.L. 1999: Chlorella virus PBCV-1 encodes a functional homospermidine synthase. Virology 263: 254-262.

KANG K.R., CHUNG S.I. 1999: Characterization of yeast deoxyhypusine synthase: PKC-dependent phosphorylation in vitro and functional domain identification. Exp. Mol. Med. 31: 210-216.

KANG K.R., WOLFF E.C., PARK M.H., FOLK J.E., CHUNG S.N. 1995: Identification of YHR068w in Saccharomyces cerevisiae chromosome VIII as a gene for deoxyhypusine synthase - expression and characterization of the enzyme. J. Biol. Chem. 270: 18408-18412.

KIERSZENBAUM F., WIRTH J.J., McCANN P.P, SJOERDSMA A. 1987: Arginine decarboxylase inhibitors reduce the capacity of Trypanosoma cruzi to infect and multiply in mammalian host cells. Proc. Natl. Acad. Sci. USA 84: 4278-4282.

KLIER H., CSONGA R., STEINKASSERER A., WÖHL T., LOTTSPEICH F., EDER J. 1995: Purification and characterization of human deoxyhypusine synthase from Hela cells. FEBS Lett. 364: 207-210.

KRAUSE T., LÜERSEN K., WRENGER C., GILBERGER T.-W., MÜLLER S., WALTER R.D. 2000: The ornithine decarboxylase domain of the bifunctional ornithine decarboxylase/S-adenosylmethionine decarboxylase of Plasmodium falciparum: recombinant expression and catalytic properties of two different constructs. Biochem. J. 352: 287-292.

KUMAR A., TAYLOR M.A., ARIF S.A.M., DAVIES H.V. 1996: Potato plants expressing antisense and sense Sadenosylmethionine decarboxylase (SAMDC) transgenes show altered levels of polyamines and ethylene: antisense plants display abnormal phenotypes. Plant J. 9: 147-158.

KYRPIDES N.C., WOESE C. 1998: Universally conserved translation initiation factors. Proc. Natl. Acad. Sci. USA 95: 224-228.

LEE C.H., PARK M.H. 2000: Human deoxyhypusine synthase: interrelationship between binding of NAD and substrates. Biochem. J. 352: 851-857.

LEE Y.B., FOLK J.E. 1997: Branched-chain and unsaturated 1,7-diaminoheptane derivatives as deoxyhypusine synthase inhibitors. Bioorg. Med. Chem. 6: 253-270.

LI F., HUA S., WANG C., GOTTESDIENER K.M. 1998: Trypanosoma brucei brucei: characterization of an ODC null bloodstream form mutant and the action of alphadifluoromethylornithine. Exp. Parasitol. 88: 255-257.

LIN P.P.C., EGLI D.B., LI G.M., MECKEL L. 1984: Polyamine titer in the embryonic axis and cotyledons of Glycine $\max (\mathrm{L}$.) during seed growth and maturation. Plant Physiol. 76: 366-371.

LUDEMANN H., DORMEYER M., STICHERLING C., STALLMANN D., FOLLMANN H., KRAUTH-SIEGEL R.L. 1998: Trypanosoma brucei tryparedoxin, a thioredoxin-like protein in African trypanosomes. FEBS Lett. 431: 381-385.

MACRAE M., KRAMER D.L., COFFINO P. 1998: Developmental effect of polyamine depletion in Caenorhabditis elegans. Biochem. J. 333: 309-315.

MAJUMDER S., WIRTH J.J., BITONTI A.J., McCANN P.P., KIERSZENBAUM F. 1992: Biochemical evidence for the presence of arginine decarboxylase activity in Trypanosoma cruzi. J. Parasitol. 78: 371-374.

MALMBERG R.L., CELLINO M.L. 1994: Arginine decarboxylase of oat is activated by enzymatic cleavage into two polypeptides. J. Biol. Chem. 269: 2703-2706.

MARTIN C., KUNSCH G., MARTIN-TANGUY J., NEGREL J., PAYNOT M., CARRE M. 1985: Effect of cinnamoyl putrescines on in vitro cell multiplication and differentiation of tobacco explants. Plant Cell Rep. 4: 158160.

MASGRAU C., ALTABELLA T., FORRAS R., FLORES D., THOMPSON A.J., BESFORD R.T., TIBURCIO A.F. 1997: Inducible overexpression of oat arginine decarboxylase in transgenic tobacco plants. Plant J. 11: 465-473.

MISHRA M., CHANDRA S., PANDEY V.C., TEKWANI B.L. 1997: Polyamine metabolism in various tissues during pathogenesis of chloroquine-susceptible and resistant malaria. Cell Biochem. Funct. 15: 229-235.

MISTRY S.K., BURWELL T.J., CHAMBERS R.M., RUDOLPH-OWEN L., SPALTMANN F., COOK W.J. 2002: Cloning of human agmatinase. An alternate path for polyamine synthesis induced in liver by hepatitis B virus. 
Am. J. Physiol. Gastrointest. Liv. Physiol. 282: G375G381.

MÜLLER S., COOMBS G.H., WALTER, R.D. 2001: Targeting polyamines of parasitic protozoa in chemotherapy. Trends Parasitol. 17: 242-245.

MÜLLER S., DA'DARA A., LÜERSEN K., WRENGER C., DAS GUPTA R., MADHUBALA R., WALTER R.D. 2000: In the human malaria parasite Plasmodium falciparum polyamines are synthesized by a bifunctional ornithine decarboxylase, S-adenosylmethionine decarboxylase. J. Biol. Chem. 275: 8097-8102.

MÜLLER S., HUNTER K.J., WALTER R.D. 1996: Effect of haloallylamines on polyamine oxidase activity and spermine levels in Ascaris suum. Parasitol. Res. 85: 571573.

MUTOMBA M.C., FUNGSHENG L., GOTTESDIENER K.M., WANG C.C. 1999: A Trypanosoma brucei blood stream form mutant deficient in ornithine decarboxylase can protect against wild-type infection in mice. Exp. Parasitol. 91: 176-184.

OBER D., HARTMANN T. 1999a: Deoxyhypusine synthase from tobacco - cDNA isolation, characterization, and bacterial expression of an enzyme with extended substrate specificity. J. Biol. Chem. 274: 32040-32047.

OBER D., HARTMANN T. 1999b: Homospermidine synthase, the first pathway-specific enzyme of pyrrolizidine alkaloid biosynthesis evolved from deoxyhypusine synthase. Proc. Natl. Acad. Sci. USA 96: 14777-14782.

OBER D., HARTMANN T. 2000: Phylogenetic origin of a secondary pathway: the case of pyrrolizidine alkaloids. Plant Mol. Biol. 44: 445-450.

PANDYA U., SAXENA J.K., SHUKLA O.P. 1997: Filarial DNA and its interaction with polyamines and antifilarial drugs. J. Helminthol. 71: 325-332.

PARK M.H., JOE Y.A., KANG K.R. 1998: Deoxyhypusine synthase activity is essential for cell viability in the yeast Saccharomyces cerevisiae. J. Biol. Chem. 273: $1677-$ 1683.

PARK M.H., WOLFF E.C. 1988: Cell-free synthesis of deoxyhypusine. Separation of protein substrate and enzyme and identification of 1,3-diaminopropane as a product of spermidine cleavage. J. Biol. Chem. 263: 15264-15269.

PERSSON K., ASKUD I., GRAHN B., HAHNKE J., HEBY O. 1998: Trypanosoma cruzi has not lost its S-adenosylmethionine decarboxylase: characterization of the gene and the encoded enzyme. Biochem. J. 333: 527-537.

PHILLIPS M.A., COFFINO P., WANG C.C. 1987: Cloning and sequencing of the ornithine decarboxylase gene from Trypanosoma brucei. J. Biol. Chem. 262: 8721-8727.

PIACENZA L., PELUFFO G., RADI R. 2001: L-argininedependent suppression of apoptosis in Trypanosoma cruzi: contribution of the nitric oxide and polyamine pathways. Proc. Natl. Acad. Sci. USA 98: 7301-7306.

PIECKENSTAIN F.L., GÁRRIZ A., CHORNOMAZ E.M., SÁNCHEZ D.H., RUIZ O.A. 2001: The effect of polyamine biosynthesis inhibition on growth and differentiation of the phytopathogenic fungus Sclerotinia sclerotiorum. Plant Mol. Biol. 80: 245-253.
PORCEL B.M., TRAN A.N., TAMMI M., NYARADY Z., RYDAKER M., URMENYU T.P., RONDINELLI E., PETTERSON U., ANDERSSON B., ASLUND L. 2000: Gene survey of the pathogenic protozoan Trypanosoma cruzi. Gen. Res. 10: 1103-1107.

REGUNATHAN S., REIS D.J. 2000: Characterization of arginine decarboxylase in rat brain and liver: distinction from ornithine decarboxylase. J. Neurochem. 74: 22012208.

RIOU J.F., GABILLOT M., PHILLIPE M., SCHREVEL J., RIOU G. 1986: Purification and characterization of Plasmodium berghei DNA topoisomerase I and topoisomerase II - drug action, inhibition of decatenation and relaxation, and stimulation of DNA cleavage. Biochemistry 25: 1471-1479.

ROBERTS S.C., JIANG Y.Q., JARDIM A., CARTER N.S., HEBY O., ULLMAN B. 2002a: Genetic analysis of spermidine synthase from Leishmania donovani. Mol. Biochem. Parasitol. 115: 217-226.

ROBERTS S.C., SCOTT J., GASTEIER J.E., JIANG Y., BROOKS B., JARDIM A., CARTER N.S., HEBY O., ULLMAN B. 2002b: S-adenosylmethionine decarboxylase from Leishmania donovani: molecular, genetic, and biochemical characterization of null mutants and overproducers. J. Biol. Chem. 277: 5902-5909.

SHEN H.J., GALSTON A.W. 1985: Correlations between polyamine ratios and growth patterns in seedling roots. Plant Growth Regul. 3: 353-363.

STRONG W.B., NELSON R.G. 2000: Preliminary profile of the Cryptosporidium parvum genome. Mol. Biochem. Parasitol. 107: 1-32.

TALADRIZ S., RAMIRO M.J., HANKE T., LARRAGA V. 2002: S-adenosylmethionine decarboxylase from Leishmania infantum promastigotes: molecular cloning and differential expression. Parasitol. Res. 88: 421-426.

TAO Y., CHEN K.Y. 1995a: Purification of deoxyhypusine synthase from Neurospora crassa to homogenity by substrate elution affinity chromatography. J. Biol. Chem. 270: 383-386.

TAO Y., CHEN K.Y. 1995b: Molecular cloning and functional expression of Neurospora deoxyhypusine synthase cDNA and identification of yeast deoxyhypusine synthase cDNA. J. Biol. Chem. 270: 23984-23987.

TETAUD E., MANAI F., BARRETT M.P., NADEAU K., WALSH C.T., FAIRLAMB A.H. 1998: Cloning and characterization of the two enzymes responsible for trypanothione biosynthesis in Crithidia fasciculata. J. Biol. Chem. 273: 19383-19390.

THOLL D., HARMS R., LUDWIG A., KAISER A. 1998: Retarded growth of an Escherichia coli mutant deficient in spermidine synthase can be unspecifically repaired by addition of various polyamines. World J. Microbiol. Biotech. 14: 857-863.

THOLL D., OBER D., MARTIN W., KELLERMANN J., HARTMANN T. 1996: Purification, molecular cloning and expression in Escherichia coli of homospermidine synthase from Rhodopseudomonas viridis. Eur. J. Biochem. 240: 373-379. 
TIBURCIO A.F., KAUR-SAWHNEY R., GALSTON A.W. 1990: Polyamine metabolism. Biochem. Plants 16: 283324.

TRULL M.C., HOLAWAY B.L., MALMBERG R.L. 1992: Development of stigmatoid anthers in a tobacco mutant: implications for regulation of stigma differentiation. Can. J. Bot. 70: 2339-2346.

VAN NIEUWENHOVE S., SCHECHTER P.J., DECLERCQ J., BONÉ G., BURKE J., SJOERDSMA A. 1985: Treatment of gambiense sleeping sickness in the Sudan with oral DFMO (DL- $\alpha$-difluoromethylornithine), an inhibitor of ornithine decarboxylase; first field trial. Trans. R. Soc. Trop. Med. Hyg. 79: 692-698.

VOGEL H.J., BONNER D.M. 1956: Acetylornithinase of Escherichia coli: partial purification and some properties. J. Biol. Chem. 218: 97-106.

WALTER R.D. 1988: Polyamine metabolism of filaria and allied parasites. Parasitol. Today 4: 18-20.

WANG T.W., LU L., WANG D., THOMPSON J.E. 2001: Isolation and characterization of senescence-induced cDNAs encoding deoxyhypusine synthase and eukaryotic translation initiation factor 5A from tomato. J. Biol. Chem. 276: 17541-17549.
WITTICH R.M., WALTER R.D. 1990: Putrescine N-acetyltransferase in Onchocerca volvulus and Ascaris suum, an enzyme which is involved in polyamine degradation and release of N-acetylputrescine. Mol. Biochem. Parasitol. 38: $13-18$.

WÖHL T., KLIER H., AMMER H., LOTTSPEICH F., MAGDOLEN P. 1993: The HYP2 gene of Saccharomyces cerevisiae is essential for aerobic growth: characterization of different isoforms of the hypusine-containing protein Hyp2p and analysis of gene disruption mutants. Mol. Gen. Genet. 241: 305-311.

WOLFF E.C., LEE Y.B., CHUNG S.I., FOLK J.E., PARK M.H. 1995: Deoxyhypusine synthase from rat testis: purification and characterization. J. Biol. Chem. 270: $8660-8666$.

WRIGHT P.S., BEYERS T.L., CROSS-DOERSEN D.E., McCANN P.P., BITONTI A.J. 1991: Irreversible inhibition of S-adenosylmethionine decarboxylase in Plasmodium falciparum-infected erythrocytes: growth inhibition in vitro. Biochem. Pharmacol. 41: 1713-1718.

ZUK D., JACOBSEN A. 1998: A single amino acid substitution in yeast eIF5A results in mRNA stabilization. EMBO J. 17: 2914-2925.

Accepted 3 September 2002 